\title{
RADIATING MUSEUMS - MECHANISM OF POSITIVE EXTERNALITIES OF OPERATIONS OF CASTLE AND PALACE MUSEUMS IN POLAND FOR COMPANIES IN LOCAL TOURISM SECTOR
}

\author{
Katarzyna OBLĄKOWSKA ${ }^{\mathrm{a}}$ \\ ${ }^{a}$ Warsaw School of Economics, Collegium of Socio-Economics, Wiśniowa 41, 02-520 Warsaw, Poland, \\ oblakkasia@gmail.com
}

Cite this article: Obłąkowska, K. (2020). Radiating Museums - Mechanism of Positive Externalities of Operations of Castle and Palace Museums in Poland for Companies in Local Tourism Sector. Deturope 12(2), 39-55.

\begin{abstract}
The purpose of this paper is to describe positive externalities of operations of castle and palace museums in Poland for private companies in local tourism sector. The paper presents the results of the author's original research, which was based on the multiple case study method. Results show that castle and palace museums in Poland generate positive externalities for private business operations in local tourism sector in three forms, i.e.: location, view and image. They appear in production functions of firms in the shape of: a reduction of customer acquisition costs, a reduction of production costs due to economies of scale, a creative contribution to product, logo, name and brand. A model of the impact of the operations of castle and palace museums on the production function of local tourism companies through the mechanism of external effects has been named: Museum Radiation Model.
\end{abstract}

Key words: externalities, museum, tourism, cultural heritage tourism

\section{INTRODUCTION}

Cultural heritage has multivariate influence on the contemporary development processes. It provides values, benefits and facilities, which are extending in dimensions of science and knowledge, art and aesthetics, collective memory, social identity, solidarity, usefulness and economy, to the whole contemporary society, and to future generations. In each of these perspectives, it is multidimensional. It includes historic palaces and castles, as well as museums that take care of, study and display such places. The main hypothesis of this article concerns the economic impact of cultural heritage on local economy. It says that the operations of the castle and palace museums influence the local economy through the mechanism of externalities. This hypothesis was verified on the basis of a study conducted on the basis of 20 case studies of castle and palace museums in Poland.

Externality is a special type of influence. We observe it when museum don't receive any 'top-up' for using their production from users. So the aim of the research was to look for private 
companies which used museum products in their production function without any financial relations between those companies and museums (that means it takes place outside a market) and without the implementation of any public finance tool (for example special taxes paid by those companies for museums).

Verifying the hypothesis of this article was one of the objectives of the study entitled "Externalities generated through activities of castle and palace museums in Poland" (grant no: UMO-2016/21/N/HS4/02879, National Science Centre, Poland), which was undertaken by the author of this paper in 2017-2019. A micro level supply-side approach was adopted, referring to the Theory of Externalities, as well as to the theories of Public Goods and Market Failures. The study allowed for the creation of a model of the impact of castle and palace museums operation on the production function of companies in the local tourism sector through the mechanism of externalities. This model has been named Museum Radiation Model. The objective of this paper is to present the results of this research in the field of verification of the hypothesis presented above, and to present the model.

\section{Externalities in the Production Function}

According to the Theory of Externalities on a micro level and from the supply-side approach, an externality is a specific company Z's influence on company $\mathrm{X}$, which is characterized by three features: 1) non-financial, noticeable and compulsory nature, 2) it is recognizable in the production function of company $\mathrm{X}, 3$ ) it generates results in the form of costs or benefits for the production volume of company X. This is the link outside the market (without agreements and payments) with market effects.

Production capacities of a company in the tourism industry are determined on the basis of the production function, determining the maximum production volume $(Q)$ that can be achieved at a given level of expenditure of production factors. The following value-creating factors are included in the production function of a modern company: labour (human capital) $(L)$, capital $(K)$, land $(T)$, entrepreneurship $(E)$, organisation $(O)$, information $(I)$, technology $(\mathrm{Tec})$, social capital $(S c)$, effectiveness $(\tau)$, and effects of scale $(\gamma)$ [McConnel \& Brue, 1990, pp. 22-23; Sztaba, 2007, p. 79; Beyer 2011, pp. 8-9; Kachniewska \& Nawrocka 2012, pp. 82-83; Klonowska-Matynia \& Palinkiewicz 2013, pp. 29-31; Machaj 2016, pp. 19-20]. There are three forms of land use in the production process: cultivation, exploitation and location. In service activities, that is also in tourism, land plays a role as a location factor, which denotes 
the location of the size and type of economic activity, facility or complex of facilities in a specific area [Jończyk i Kaczor, 2020].

The Theory of Externalities adds one more factor to those listed above, that is Qz, meaning the production volume of an external company $\mathrm{Z}$ versus $\mathrm{X}$, which has noticeable and compulsory effects on the production volume of the company $X$, i.e., results in its increase or decrease without market (financial) relationships between $\mathrm{Z}$ and $\mathrm{X}$, without $\mathrm{Z}$ paying attention to $\mathrm{X}$ 's wellbeing, and without X participating in any production decisions of Z [Scitovsky 1954, p. 146; Baumol, Oates 1998, pp. 16-18, Papandreou 2007, pp. 46-48, 58-59]. Therefore, taking into account $\mathrm{Qz}$, the company production function can be described in the following formal way:

Equation 1. Formula for production function

$$
Q_{x}=f\left(L, K, T, E, O, I, T e c, S c, \tau, \gamma, Q_{z}\right),
$$

where:

$\mathrm{Q}_{\mathrm{x}}$ - production volume for company $\mathrm{X}$

$\mathrm{L}$ - labour

K - capital

$\mathrm{T}-$ land

E - entrepreneurship

$\mathrm{O}-$ organization

I - information

Tec - technology

Sc - social capital

$\tau$ - effectiveness

$\gamma-$ scale effect

$\mathrm{Q}_{\mathrm{z}}$ - production volume for company $\mathrm{Z}$, as an externality.

In the theory, the production volume of company $\mathrm{Z}$ may have either a positive or a negative effect on the production volume of company X. Negative externalities of company Z's operations are perceived as damages, while their positive externalities are perceived as benefits by company $\mathrm{X}$. Company $\mathrm{Z}$ may even not notice such effects of its operations, while company $\mathrm{X}$ must feel this influence. The production of company $\mathrm{Z}$ is included in the production function of company $\mathrm{X}$ as an unpaid, noticeable (appreciable) and compulsory factor [Papandreou 2007, pp. 48, 59]. Positive effects are often an item used consciously.

The negative influence is extensively scientifically described from the point of view of the natural environment [Papandreou 2007, pp. 46, 69]. By polluting (degrading) the natural environment, company $\mathrm{Z}$ shifts the costs of its operations onto business entities which use a clean (unpolluted) natural environment for their production or onto the state which, in the name 
of society, accepts as its task providing a clean (undegraded) natural environment for the current and future generations. Several methods are used to ensure internalisation of external costs, i.e. including negative externalities generated by the company in the accounting of the polluting company. These are: the Pigouvian $\operatorname{tax}^{2}$, a system of government regulations, concessions and limits, a system of tradable emission permits, direct negotiations, and court rulings [Pigou 2013, p. 192; Coase 1960, pp. 3-5, 43-44; Jewtuchowicz 1987, p. 20; Czarny 2011, pp. 291-293; Klimczak 2015, p. 466; N.G. Mankiv, M.P. Taylor 2015, pp. 385-289; Kudełko 2016, p. 339].

Positive effects transferred to a third party, from which collecting payment is technically very difficult to proceed, were indicated from the very beginnings of the Theory of Externalities development. The examples of operations generating positive externalities include providing public goods: operations of a provider of lighthouse light (the effect: light for all passing ships); operations of a beekeeper beneficial for a fruit-grower (the effect: bees pollinating orchard plants), but also of a fruit-grower (because the production volume of the beehive owner depends, amongst others, on the production volume of the fruit-grower); operations of owners in towns making gardens on their private grounds (the effect: a beautiful view, improved quality of air) and lighting private buildings (the effect: the street is lit for all pedestrians), and outside towns, planting forests on their private grounds (the effect: improved quality of air, higher precipitation); research studies (the effect: innovations and lower prices); historic monuments/buildings conservation (the effect: beautiful view of the façades) [Pigou 2013, pp. 135, 183-185; Meade 1952, pp. 63-64; Stiglitz 2004, p. 95; Benhamou 2013, s. 5]. The biggest problem with the operations generating positive externalities combines with the unprofitability of taking them (Acocella 2002, p. 81). One of the methods for solving this problem is subsidization from public funds.

In accordance with the assumptions of the Economics of Culture, the museum was treated in the study as a special type of enterprise that can produce goods that enter the production function of local enterprises as production factors [Towse 2011: 265]. A positive externality of museum operations, therefore, is a museum influence on the company, which is recognised in the production function of this company and generates affirmative results in the form of benefits for its production volume, and this influence has non-financial, noticeable and compulsory nature.

\footnotetext{
${ }^{2}$ Named after Arthur Pigou (1877-1959), who established foundations for the theory of externalities and who was the first to recognise the state intervention (through taxes and subsidies) as a factor restoring a balance between a private and a social product/cost in a situation where externalities exist in conditions of a free competition.
} 


\section{DATA AND METHODS}

The castle/palace museum is a non-profit, permanent organizational unit open to the public, which permanently acquires, conserves, researches, communicates and exhibits tangible and intangible heritage for the purposes of education, study and enjoyment, located in a historic castle or palace [The Museums Act of 21 November 1996, art 1]. It usually refers in its name to the castle/palace, where it is located, and this castle/palace is a basic part of its identity. According to information from the National Institute for Museums and Public Collections in Poland, in 2017 in Poland there were 28 museums with the words 'castle' or 'palace' in their names. Three of them were in the process of formation during the research period. There were also museums located in historic castles or palaces, which did not have the words 'castle' or 'palace' in their names, but the historical castles or palaces were a core element of their identities and the heritage which they protected.

To find out if and how the mechanism of externalities works, the research based on a multiple case study method was conducted. It included 20 case studies of economic environments organised around castle/palace museums in Poland. All the castles and palaces, where the museum centers of investigated environments were and are located, are included in the Polish Immovable Historic Monuments List. Figure 1 shows the location of those museums on the map of Poland. Each of these museums performs tasks imposed on them by the law in: the Museums Act 1996, the Act on Organising and Engaging in Cultural Activity 1991, and the Act on Heritage Protection and Maintenance 20033. However, they differ. They are characterised by a different history, status, value of assets, annual budget, visitor numbers and other differences. The majority of them are state or self-government museums. One is maintained by a foundation established by a state-owned company. One museum is maintained by a nongovernmental organisation. One is maintained by a private foundation, and one by a private person. In Poland, the castles belong to a category of historic buildings with the highest transregional recognition amongst society [Obłąkowska-Kubiak 2017, p. 256]. Their heritage nature is considered obvious and generally accepted [NID 2017, p. 124].

\footnotetext{
${ }^{3}$ The Museums Act of 21 November 1996, Journal Laws of 1997, No. 5, item 24, as amended; The Act on organising and engaging in cultural activity of 25 October 1991, Journal Laws of 1991, No. 114, item 493, as amended; The Act on heritage protection and maintenance of 23 July 2003, Journal Laws of 2003, No. 162, item 1568 , as amended.
} 
Figure 1 A map of Poland with locations of museums - centres of case studies

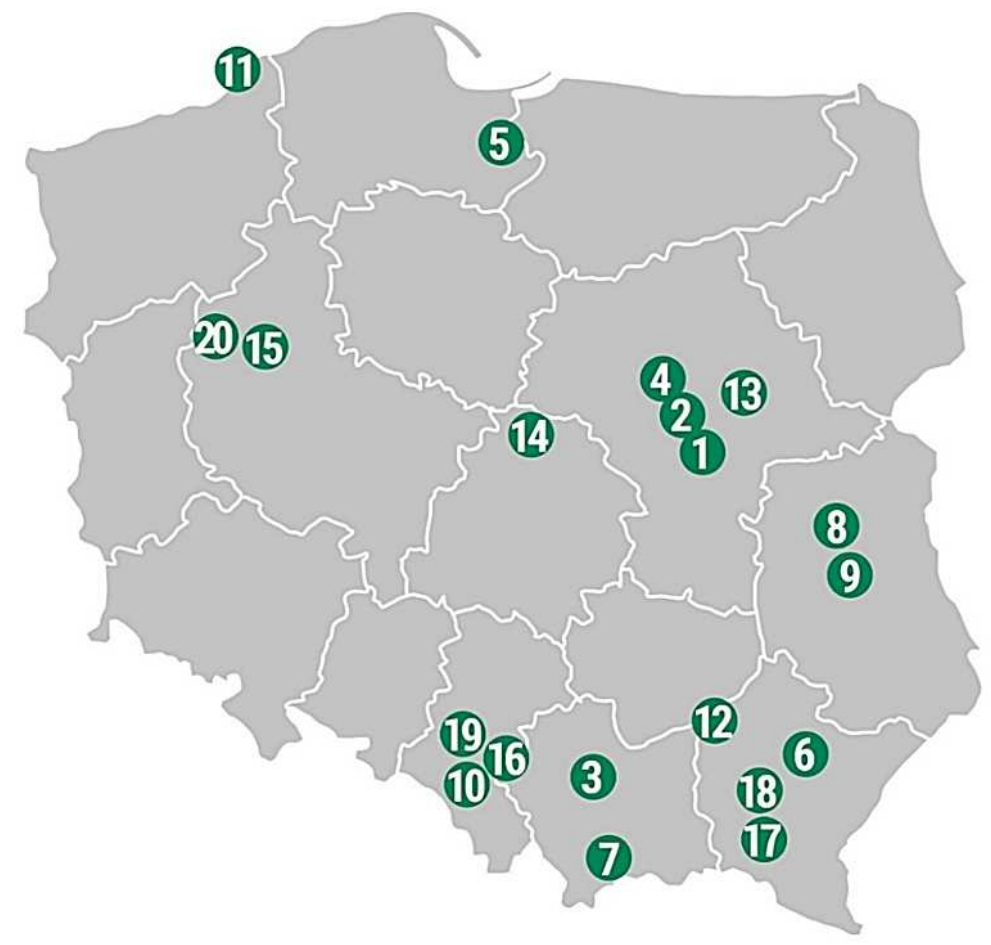

\begin{tabular}{l}
$\frac{1 \text { Muzeum of King Jan III's Palace at Wilanów }}{2 \text { The Royal Łazienki Museum }}$ \\
\hline 3 Wawel Royal Castle - State Art Collection \\
\hline 4 The Royal Castle in Warsaw - Museum \\
\hline 5 The Malbork Castle Museum \\
\hline 6 Castle Museum in Łańcut \\
\hline 7 The Niedzica Castle Complex - Museum \\
\hline 8 The Zamoyski Museum in Kozłówka \\
\hline 9 Lublin Museum - The Lublin Castle \\
\hline 10 The Castle Museum in Pszczyna \\
\hline 11 Castle of the Pomeranian Dukes - Museum in Darłowo \\
$\frac{12 \text { Baranów Sandomierski-Castle and Park Complex }}{13 \text { The Museum Armoury in Liw Castle }}$ \\
\hline 14 Museum - Castle in Oporów \\
\hline 15 The Górkas' Castle Museum in Szamotuły \\
\hline 16 Castle Museum in Oświęcim \\
\hline 17 Historical Museum - Palace in Dukla \\
\hline 18 Castle Museum Kamieniec \\
\hline 19 Castle Museum in Chudów \\
\hline 20 Museum Opaliński Castle in Sieraków
\end{tabular}

Source: Own study.

The research was conducted in the period from March 2017 to December 2019 by the author of this text. The author did all research by herself. Its methodology was based on the technique of triangulation (combination of several research methods and validation of data through cross verification from two or more sources). The following research methods were employed ${ }^{4}$ :

a) a field observation with photographic documentation (20) - in a field study, one environment was an area within a circle of the radius of ca. $500 \mathrm{~m}(1640 \mathrm{ft})$, with the museum being its centre,

b) a map of externalities (20) - a map indicating the location of the 'companies - museum externalities recipients',

c) a questionnaire interview with the following groups of respondents: museum directors or representatives (5), village leaders, town mayors or presidents (13), customer service employees (225 companies), company owners (31),

d) an analysis of website content of private companies (153), communes (22) and museums (20),

e) an analysis of printed promotional materials (47 companies),

f) desk research: an analysis of literature, public statistics and museums' financial reports.

\footnotetext{
${ }^{4}$ The number of observations, interviews and analyses is provided in brackets.
} 


\section{RESULTS}

The results of the research have shown that the operations of castle and palace museums in Poland generate positive externalities for private business operations in the form of: location, view and image. These products are not the purpose for which museums operate. However, they are not by-products of their activities. Museums care about it. Those externalities appear in production functions of firms in the shape of: a reduction of customer acquisition cost, a reduction of production costs due to economies of scale, a creative contribution to the product, logo, name and brand. Those factors, included in the production functions of private companies in the tourism sector, bring them an economic advantage.

In the research, those externalities were identified in the production functions of the 262 companies. The greatest number of externalities recipients operated in the hotel-restaurant-café industry (HoReCa) (110 entities) ${ }^{5}$. The largest second group included companies described as "creative," as they use, directly or indirectly (in their products), a high extent of cultural and artistic values (93 entities) ${ }^{6}$. It was followed by groups operating in trade (47 entities) ${ }^{7}$, and transport $(9 \text { entities })^{8}$. Two companies operating in construction investment processes, and one in a beauty parlour. The majority of identified entities operated only in a local market (222), in the immediate vicinities of the museums. However, there were also those operating in domestic (38) and international (2) markets.

The study allowed for the creation of a model of the impact of active castle and palace museums on the production function of companies in the local tourism sector through the mechanism of externalities. The externality 'location' has a positive impact on the production function of local firms as a reduction of customer acquisition cost and as a reduction of production costs due to economies of scale. The externality 'view of a castle/palace museum' as part of a location was part of services (for example as sceneries of restaurant and café gardens, or in the work of photographers and guides). This externality was also a creative contribution to products (for example souvenirs) and to companies' logos. The externality 'image of a castle/palace museum' was becoming a creative contribution to companies' names and brands.

\footnotetext{
${ }^{5}$ Restaurants, fast foods, snack bars, cafés, ice cream parlours, waffles, hotels and accommodation facilities, mobile catering facilities, alcoholic beverages.

${ }^{6}$ Local trips organizers and tour guides, individual painters, souvenir manufacturers, photographic operations, art $\&$ craft \& antique galleries, jewellery shops.

${ }^{7}$ Souvenirs/gift shops, grocery shops, bakeries, patisseries, newsagents.

${ }^{8}$ Car parks, taxi.
} 
These results confirm formula 1 of the production function in the area of including positive externalities generated through active castle and palace museums in the production function of local enterprises in tourism sector. It also indicates the need to add creativity to this formula. It shows that new products are rooted in the reintegration of pre-existing materials and knowledge, but obviously, an innovative product - when completed - contains elements that are completely new [Stein 1953, p. 311]. "Creative thinkers go beyond the past to produce genuinely novel ideas and objects" [Weisberg 2006, p. 54].

\section{Externality: Location}

Museums attract visitors. This is a basic characteristic of a location with a museum. A visitor is a person (traveler) taking a trip to a main destination outside his/her usual environment, for less than a year, for any main purpose (personal, business) other than to be employed by a resident entity in the country or place visited, other than migration (economic, internal, external, circular, seasonal, temporary, permanent). A visitor brings money from outside into the destination. Visitors are classified as tourists (persons whose trip includes an overnight stay) and as excursionists (persons whose trip does not include an overnight stay) [UNWTO, p. 4]. In 2016, museums centres of case studies were visited by over 9.5 million people in total. The most frequently visited locations were: The Museum of King Jan III's Palace at Wilanów (3.1 mln), The Royal Łazienki Museum in Warsaw (2.1 million), The Wawel Royal Castle - State Art Collection (1.4 million), The Royal Castle in Warsaw - Museum. The Residence of Kings and the Republic of Poland (668 000) and The Malbork Castle Museum (609 000).

Location as an external effect of operations of museums allows the companies firstly to reduce the costs of acquiring customers. And secondly it allows them to increase the scale of production and - thanks it to - reduce production costs due to economies of scale. In the research, 196 private business operations were identified, whose services were used by museum visitors. Most of them operated in HoReCa sector (105 entities) and trade sector (46 entities). They were followed by companies from the creative sector (35 entities), transport ( 9 entities) and beauty industry (1 entity).

\section{Externality: View}

A view is the visible space. It represents something that can be taken in by an eye, sight, and perception. It is a fragment of space, area, landscape, or scenery, filled with details [Słownik Języka Polskiego PWN 2017; English Oxford Living Dictionaries 2017]. The view of a castle/palace museum is a result of historical and contemporary human activities and its 
interactions with nature. It is shaped by its history and contains products of a civilisation, and natural components. The heritage landscape ensures a unique view, rarely encountered, of specific aesthetics and biography [Kobyliński 2014, pp.13-15].

The results of the research showed that the view of castle and palace museums (of castles and palaces) became the core, a component or an inspiration for various products and services. Products include souvenirs, interior design items, paintings, photographic wallpapers, flats (flats with a view). Services cover restaurants and cafés (scenery of those places and view from those places), accommodation services (view from hotel windows), touristic guidance, outdoor photography (scenery for photographers' works), painting (subjects of paintings). The view of a museum/castle/palace is becoming a creative contribution to products and services in a production function. Three types of views were included by companies in their production functions, i.e.

- Direct "compulsory" view - the nearest view experienced from a restaurant, café, hotel, or a flat.

- Direct voluntary view - offered to customers by guides; transferred onto various products ${ }^{9}$ by companies manufacturing souvenirs; used by painters as a theme of their paintings; used by photographers as a scenery of offered photo sessions (mainly weddings).

- Transposed view - the view of a castle/palace in another form (painting, photograph, photographic wallpaper) used in an interior design being a component of a service offered to customers (restaurant, café, hotel interiors).

In the research, 113 companies who took this externality were identified. 26 entities provided services relating to organising a visit and guiding visitors. 24 were individual operations of painters. 18 provided catering services (restaurants, fast-food bars). 17 operated as souvenir manufacturers. 15 were conducting photographic operations, 10 offered accommodation, 2 were construction developers, and one was a wine producer.

Freedom of panorama (view) is a very important aspect of a view considered as an externality. This freedom becomes a production factor for companies transferring the view of the museum into souvenirs or components of the interior decorations, as well as for operations of photographers. The freedom of panorama is an exception in the Polish Copyright Act. The law allows to spread out works that are permanently exhibited to the public, without the need

\footnotetext{
${ }^{9}$ Magnets, postcards, bookmarkers, key rings, mugs, Christmas baubles, a glass (snow) globes, vodka glasses.
} 
to obtain a permit of copyright holders for these works, but not for the same function ${ }^{10}$. Therefore, it is permitted to take outside photos of architectonic objects and use them for example to prepare souvenirs or interior design decorations. The freedom of panorama also belongs to externalities, but those created by a state.

\section{Externality: Image}

An image is an impression created in human minds. It is a conceptual representation of a real subject, object, phenomenon or process. It is a combination of associations, judgements, opinions, beliefs, information, ideas, feelings and attitudes. The created image evokes associations, thus providing the object with additional value and contributing to its emotional reception. An image is part of a brand, which belongs to the company's intangible assets. The function of a brand on the one hand is to identify, distinguish and highlight goods and services in the market. On the other hand, it is to create characteristic associations in stakeholders' minds. And generally, in the end, its aim is to generate economic benefits. A brand enables the producer to use the effects of scale. A good brand is a guarantee of quality to clients. A strong brand can be a decisive factor in the market success of a given technology, product or service [Szromnik 2007, pp. 133-134; Zieliński and Kubacki 2014, p. 706; Urbanek 2012, p. 143]. A brand, a name and a logo we can perceive as parts of a social technology factor in the production function. Each brand is characterised by its spontaneous and prompted recognition and awareness.

The result of the research showed that companies used museum images in their names and logos. They used in their names words like "castle," "royal," "duke," "near the castle," "by the castle," or words associated with specified names of museums. In their logos, they use appearance (views) of museums more or less directly as creative contribution or inspiration. There were identified 23 companies whose production functions included a brand factor referring to museums in their names, and 5 in their logos. These companies operated in the following industries: restaurant and other catering facilities (9), hotels and other accommodation facilities (5), production of alcoholic beverages (beer, wine, cordials, liqueurs) (4), and other (5). Moreover, a lot of companies were also using views and names of museums

\footnotetext{
${ }^{10}$ The Copyright and Related Rights Act of 25 November 1991, Journal Laws of 1991, No. 114, item 493, as amended, Article 33.1.
} 
in their advertising operations. In the research, 71 entrepreneurs were identified who were doing it. They were using views and names of museums in their advertising leaflets, in posters and on their websites to give information about their location or about the attractions of the area. In this way, the museums were becoming a part of their product, their offer.

\section{Differences in the strength of externalities - inspirations}

It is important to point out that large differences in the strength of externalities for entrepreneurial ventures generated through the individual museums, were identified in the research. Exploration of these differences was not the aim of the project. However, this observation opens a very interesting research field. The author proposes an indicator for the strength of positive externalities for entrepreneurs according to equation 2.

Equation 2. Formula for the strength of positive externalities for entrepreneurs

$$
E x=T+V+I+A
$$

where:

Ex - an indicator for the strength of positive externalities for entrepreneurs

$\mathrm{T}$ - number of 'companies - recipients of museum location'

$\mathrm{V}$ - number of 'companies - recipients of museum view'

I - number of 'companies - recipients of museum image'

$\mathrm{A}$ - number of companies using museum image/name/view in their advertising operations

The use of this probationary indicator permitted the division of the museum centres of case studies into three groups: 'museums with high strength of positive externalities', 'those with moderate strength' and 'those with low strength'. The observations during the research allowed the author to distinguish the factors co-occurring with strong and those co-existing with weak positive external effects. The strong effects co-occurred with very valuable (in terms of scientific, historic, artistic and financial values) museum resources, high value of museum fixed assets, high annual museum budget, long history of museum operation, large numbers of museum visitors, museum location in a city, other tourist attractions within walking distance outside the museum grounds, a high level of complementary tourist services in walking distance outside the museum grounds (those services were tourist attractions themselves, they attracted the visitors). The low effects co-occurred with less valuable museum resources, low value of museum fixed assets, low annual museum budget, shorter history of museum operation, low number of museum visitors, location in a village or small town, no other tourist attractions within walking distance outside the museum grounds, none or a low level of complementary 
tourist services in walking distance outside the museum grounds, noticeable negative externalities from vicinity (for instance: degraded neighborhood, dangerous and busy street in immediate vicinity, conflict or lack of cooperation in local society). Regardless, this topic requires further research, especially regarding the synergy mechanism.

Below are three examples of maps of externalities (figures 2, 3 and 4) for museums with high strength of positive externalities for entrepreneurs. They show the locations of the companies, which are the recipients of the museums' externalities. Figure 2 shows the map of externalities of the museum Wawel Royal Castle - State Art Collection in Cracow. Figure 3 presents this map for The Malbork Castle Museum (The Castle of the Teutonic Order in Malbork). And Figure 4 displays the situation created by The Niedzica Castle museum (Dunajec Castle built by the Hungarians in Niedzica). There are also photos of these castles and their closest economic neighborhoods.

Figure 2 A map of externalities of the museum Wawel Royal Castle - State Art Collection.

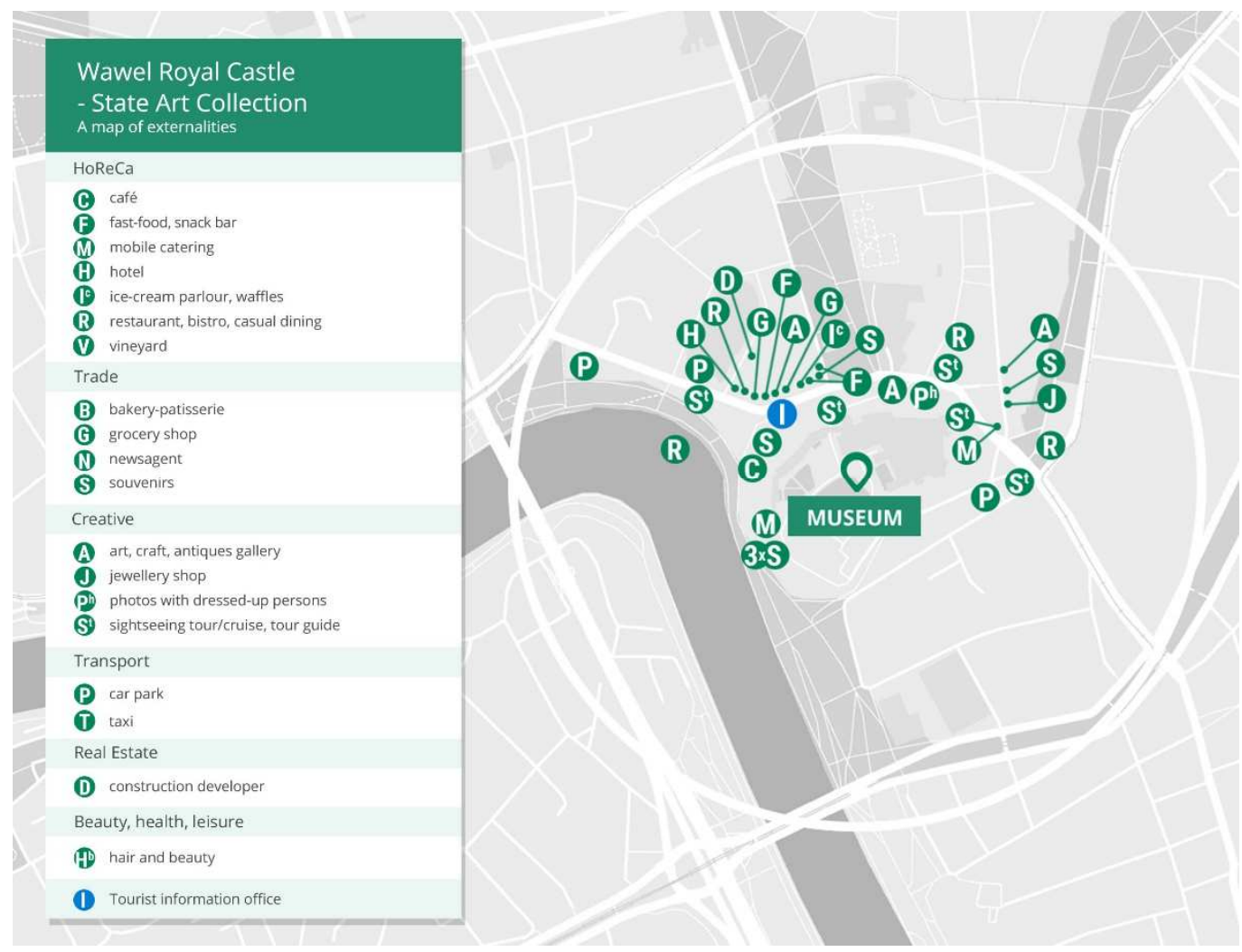

Source: Own study. 
Photo 1 Wawel Royal Castle and its economic neighbourhood

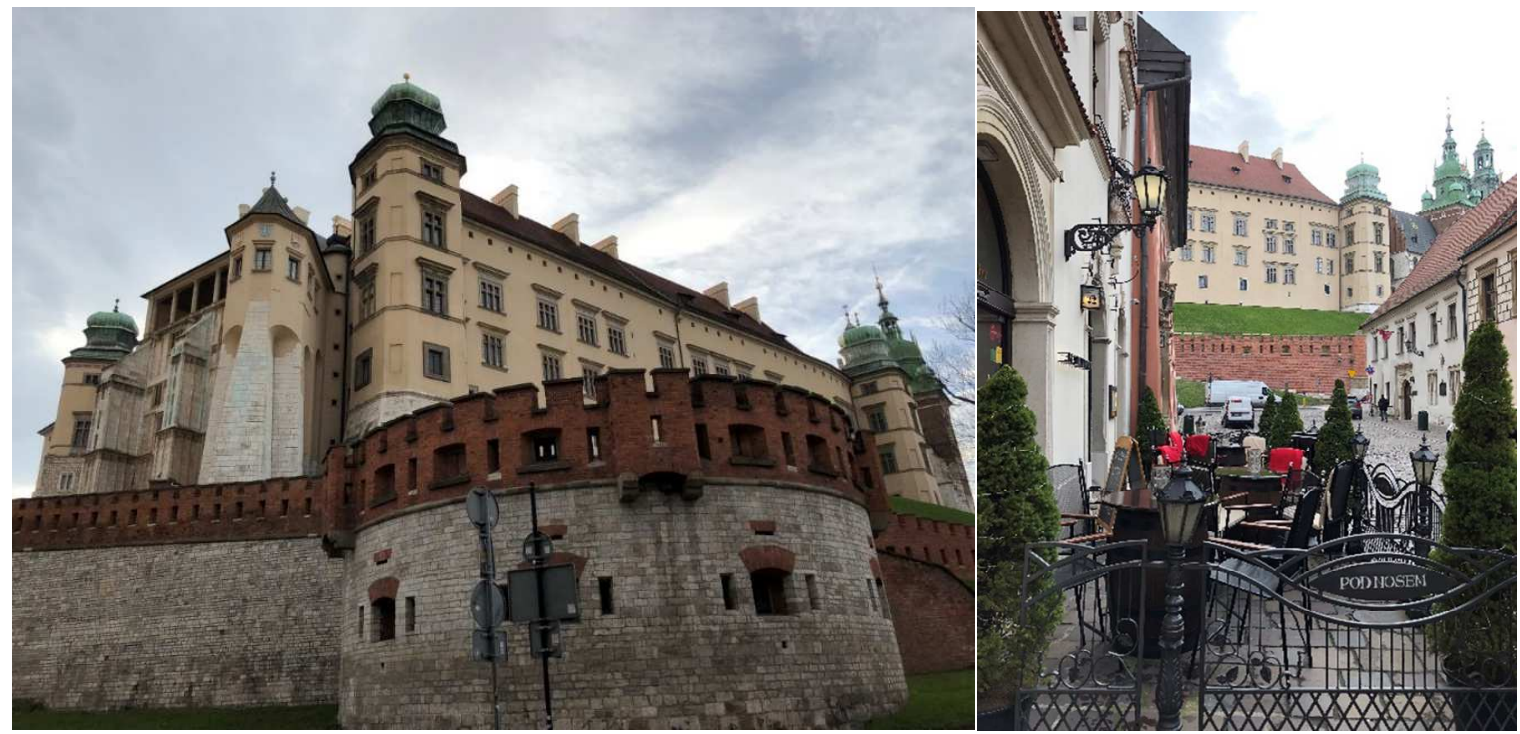

Photos by: Katarzyna Obłąkowska, 2017

Figure 3 A map of externalities of the museum The Malbork Castle Museum

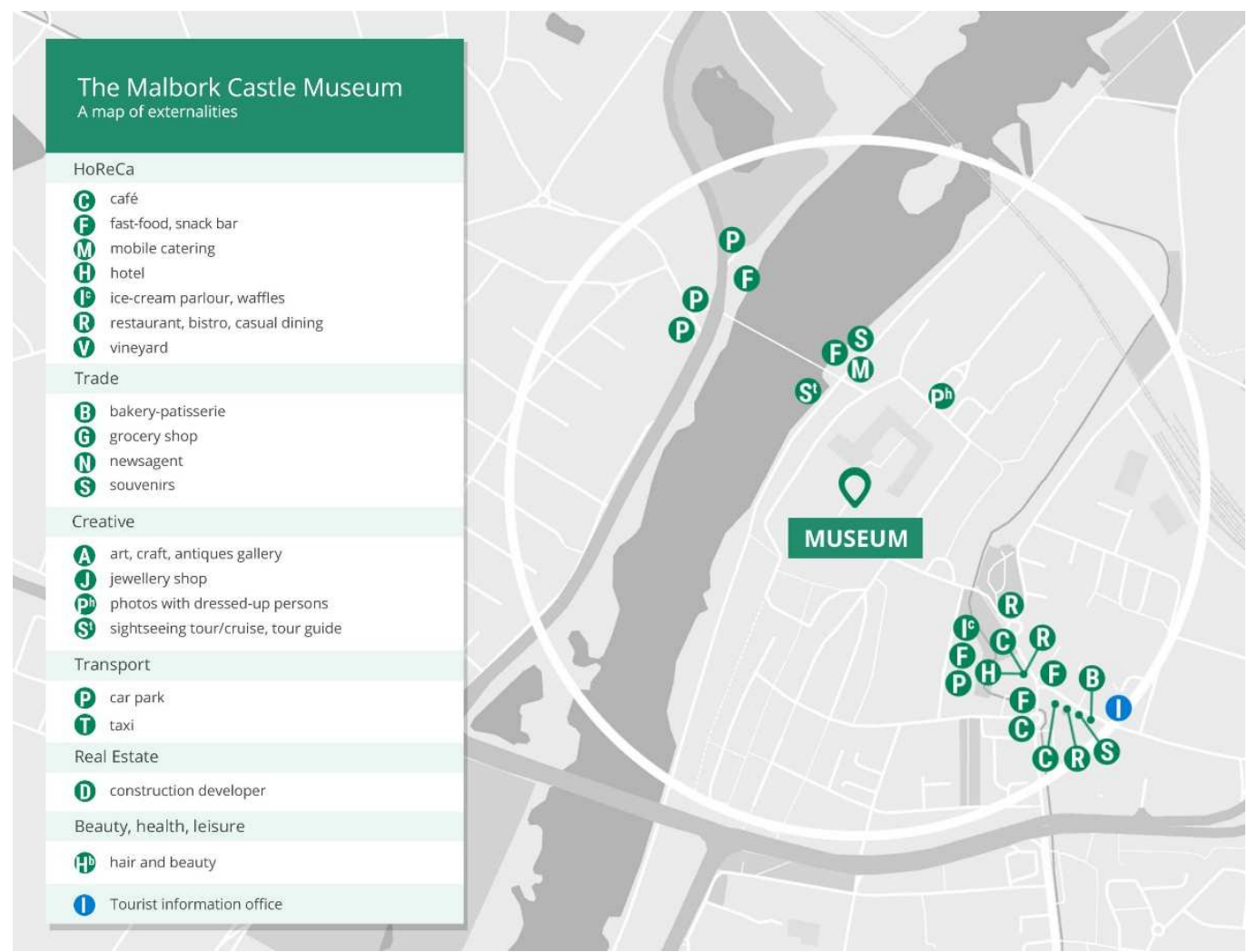

Source: Own study. 
Photo 2 The Castle of the Teutonic Order in Malbork and its economic neighbourhood
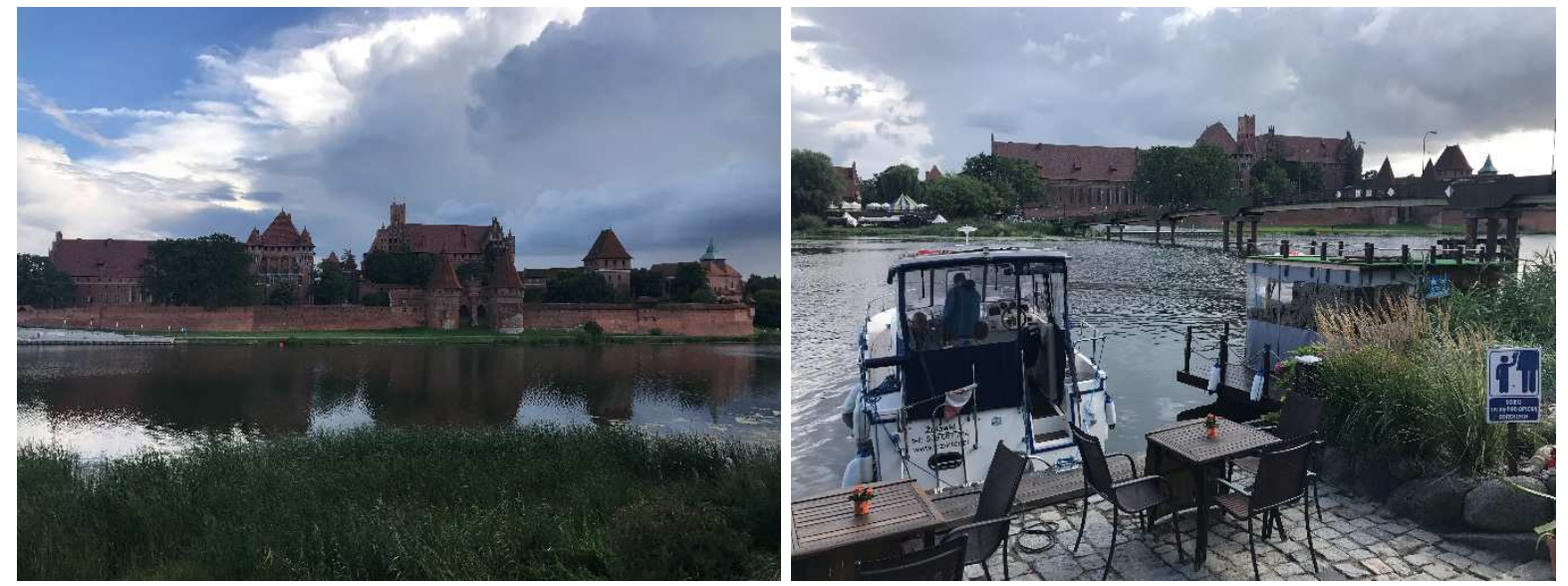

Photos by Katarzyna Obłąkowska, 2017

Figure 4 A map of externalities of the museum The Niedzica Castle.

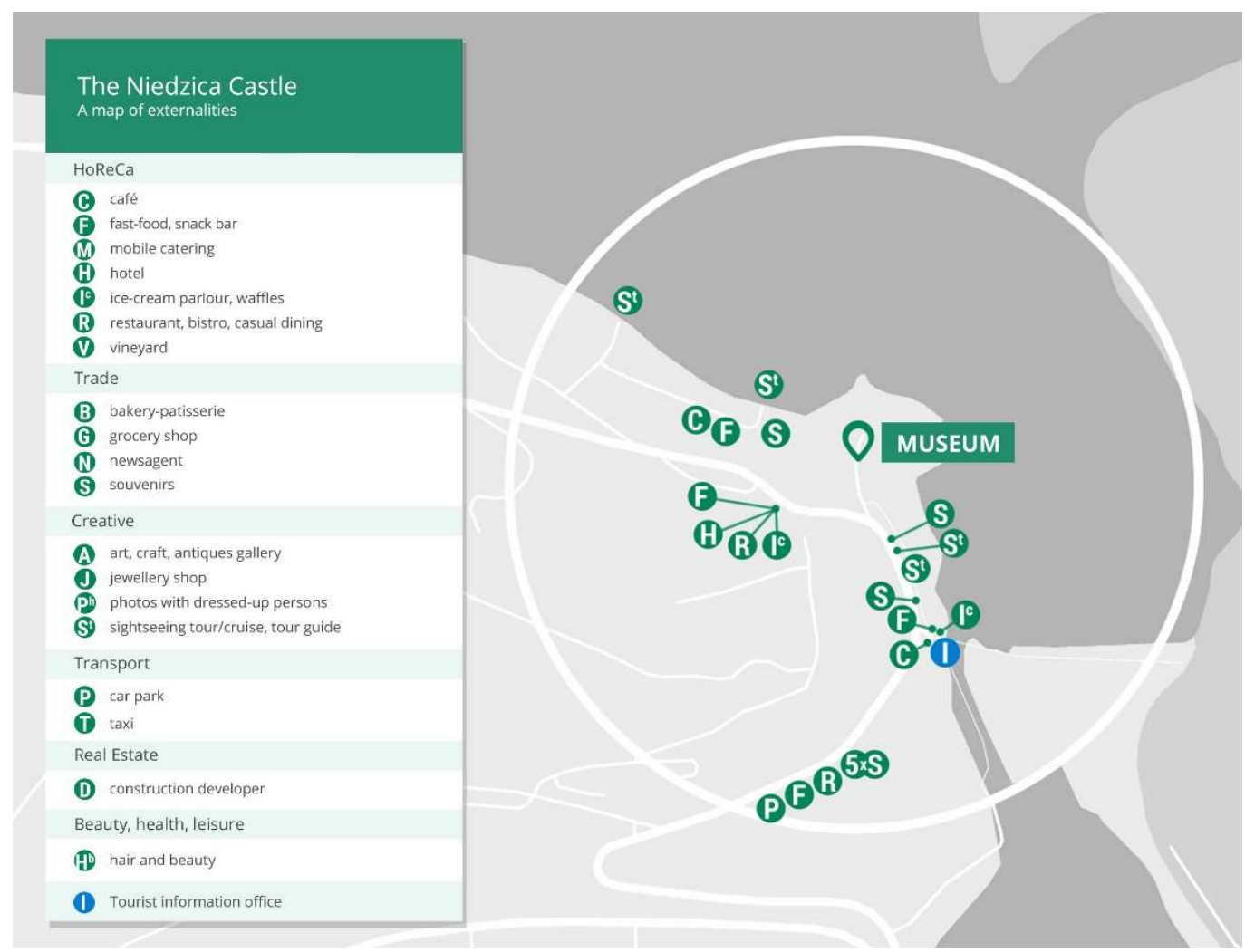

Source: Own study. 
Photo 3 Dunajec Castle in Niedzica and its economic neighbourhood

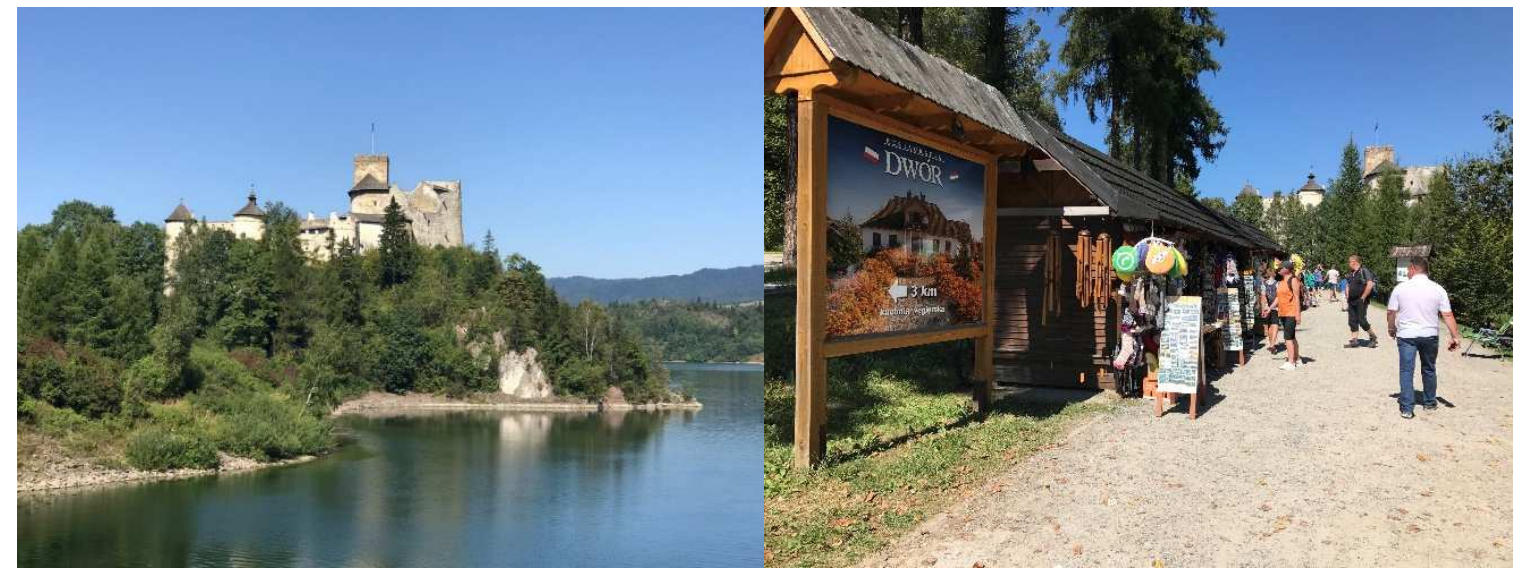

Photos by Katarzyna Obłąkowska, 2017

\section{CONCLUSIONS, AN OUTLOOK}

The castle/palace museums in Poland generate positive externalities for private business operations in the form of: location, view and image. They appear in production functions of firms as a reduction of customer acquisition cost, a reduction of production costs due to economies of scale, a creative contribution to product, logo, name and brand. The results of the research show that public and private investments into cultural heritage sites and attractions are advantageous for business operations unrelated to investors. This is consecutive evidence for public authorities for cultural heritage investment policy, as well as for the museums themselves in the aim to lead more effective fundraising. It is also useful for entrepreneurial ventures surrounding museums in better understanding how to develop services around cultural attractions.

The results of the research are also the basis for placing the question about 'rewarding' museums, which generates positive externalities, by non-investing/non-paying firms and entities, who are recipients of these externalities. This is the question about internalisation of identified externalities. A solution that can be employed here are for example direct negotiations and arrangements. But much simpler would be a special local tax paid by these firms and entities, which would be transferred to a museum budget from the budget of a local government. It should increase the level of museum incomes and reduce the incomes of entrepreneurs, owners of the buildings and landowners around museums. The situation and the level of development of each local tourist market is different. That is the reason why every solution should be tailored to a specific place, specific local needs and potential. It is very important to employ studies, knowledge, negotiations, cooperation and respect for a widely understood common good. 


\section{Acknowledgements}

Supported by National Science Centre, Poland, project: „Externalities generated through activities of castle and palace museums in Poland", UMO-2016/21/N/HS4/02879.

\section{REFERENCES}

Acoccella, A. (2002). Zasady polityki gospodarczej, Warszawa: Wydawnictwo Naukowe PWN.

Amestoy, V.A. (2013). Demand for cultural heritage. In I. Rizzo, A. Mignosa (Eds.), Handbook on the Economics of Cultural Heritage, Cheltenham, UK: Edward Elgar Publishing Limited, 89-110.

Arrow, K. J. (1969). The organization of economic activity: Issues pertinent to the choice of market versus non market allocation. In Congress of the United States, The Analysis and Evaluation of Public Expenditures: The PPB System, 47-64.

Baumol W.J. \& Oates W.E. (1998). The Theory of Environmental Policy. Second edition. Cambrige: Cambridge University Press.

Benhamou F. (2013). Public intervention for cultural heritage: normative issue and tools. In I. Rizzo, A. Mignosa (Eds.), Handbook on the Economics of Cultural Heritage, Cheltenham, UK: Edward Elgar Publishing Limited, 3-16.

Beyer K. (2011). Wiedza jako kluczowy zasób w nowej gospodarce. Studia i prace Wydziału Nauk Ekonomicznych i Zarzadzania, 21, 7-16.

English Oxford Living Dictionaries (2017). Sight. Retrieved from https://en.oxforddictionaries.com/definition/sight.

English Oxford Living Dictionaries (2017). View. Retrieved from https://en.oxforddictionaries.com/definition/view.

Florida, R. (2010). Narodziny klasy kreatywnej. Warszawa: Narodowe Centrum Kultury.

Harrison, R. (2009), What is heritage?. In R. Harrison (Ed.), Understanding the politics of heritage, Manchester: Manchester University Press.

Jewtuchowicz A. (1987), Efekty zewnętrzne w procesach urbanizacji i uprzemysłowienia . Łódź: Wydawnictwo Uniwersytetu Łódzkiego.

Jończyk, M. \& Kaczor, M. (2020) Czynniki produkcji w gospodarce turystycznej, w: Encyklopedia Zarządzania, https://mfiles.pl/pl/index.php/Czynniki_produkcji_w_ gospodarce turystycznej (05.03.2020).

Kachniewska, M., \& Nawrocka, E. (2012). Ekonomika podaży turystycznej. In M. Kachniewska, E. Nawrocka, A. Niezgoda (Eds.), Rynek turystyczny. Ekonomiczne zagadnienia turystyki, Warszawa: Oficyna a Wolters Kluwer business, 57-112.

Klonowska-Matynia, M. \& Palinkiewicz, J. (2013). Przedsiębiorczość w teorii ekonomicznej. Zeszyty Naukowe Wydziału Nauk Ekonomicznych, 17, 29-40.

Machaj. M. (2016), Wolna przedsiębiorczość. Podręcznik do nauki podstaw przedsiębiorczości. Wrocław: Instytut Ludwiga von Misesa.

Mankiw, N. G. \& Taylor M. P. (2015), Mikroekonomia. Warszawa: Polskie Wydawnictwo Ekonomiczne.

McConnel, C.R. \& Brue, S.L. (1990), Economics. Principles, Problems, and Policies. 11th edition. New York: McGraw-Hill Publishing Company.

Meade, J. E. (1952), External Economies and Diseconomies in a Competitive Situation. The Economic Journal, 62 (245), 54-67.

Mendoza, R.L. (2012). Club Goods in the Health and Wellness Sector. Current Research Journal of Economic Theory, 4(2),18-28.

Murzyn-Kupisz, M. (2012). Cultural, economic and social sustainability of heritage tourism: issues and challenges. Economic and Environmental Studies, 12 (2), 113-133. 
Murzyn-Kupisz, M. \& Działek, J. (2013). Cultural heritage in building and enhancing social capital. Journal of Cultural Heritage Management and Sustaunable Development, 3(1), 35-54.

Murzyn-Kupisz, M. (2016), Instytucje muzealne $z$ perspektywy ekonomii. Kraków: UNIVERSITAS.

Narodowy Instytut Dziedzictwa (NID) (National Heritage Board of Poland) (2017). Raport o stanie zachowania zabytków nieruchomych $w$ Polsce. Zabytki wpisane do rejestru zabytków (księgi rejestru A i C), Warszawa.

Obłąkowska-Kubiak, K. (2017). Attitudes of Polish society towards monuments and monument protection policy based on surveys. Ochrona Zabytków, 1(270) LXX, 239-267.

ODPM: Housing, Planning, Local Government and the Regions Committee (2004). The Role of Historic Buildings in Urban Regeneration. Eleventh Report of Session 2003-04, Volume I - Report, London: The House of Commons.

Papandreou, A.A. (2007). Externality and Institutions. Oxford: Clarendon Press.

Pigou, A. (2013). The Economics of Welfare. New Jork: Palgrave Macmillan.

Sandler, T. \& Tschirhart, J. (1997). Club Theory. Thirty Years Later. Public Choice, 93, 335355.

Scitovsky, T. (1954) Two Concepts of External Economies. The Journal of Political Economy, $62(2), 143-151$.

Słownik Języka Polskiego PWN (2017). Widok. Retrieved from https://sjp.pwn.pl/sjp/widok;2535768.html.

Stein, M.I. (1953). Creativity and culture. Journal of Psychology, 36(2), 311-322.

Stiglitz, J. E. (2004). Ekonomia sektora publicznego. Warszawa: Wydawnictwo Naukowe PWN.

Szromnik, A. (2007), Marketing terytorialny. Miasto i region na rynku. Warszawa: Oficyna a Wolters Kluwer business.

Sztaba S. (2007). Ekonomia od A do Z. Encyklopedia podręczna. Warszawa: Wydawnictwa Akademickie i Profesjonalne.

The Act on Organising and Engaging in Cultural Activity of 25 October 1991, Journal Laws of 1991, No. 114, item 493, as amended (Ustawa z dnia 25 października 1991 r. o organizowaniu i prowadzeniu działalności kulturalnej, Dz.U. $1991 \mathrm{nr} 114$ poz. $493 \mathrm{z}$ późn. zm.).

The Copyright and Related Rights Act of 4 February 1994, Journal Laws of 1994, No. 24, item 83, as amended (Ustawa $\mathrm{z}$ dnia 4 lutego 1994 r. o prawie autorskim i prawach pokrewnych, Dz.U. 1994 nr 24 poz. 83 z późn. zm.).

The Museums Act of 21 November 1996, Journal Laws of 1997, No. 5, item 24, as amended (Ustawa z dnia 21 listopada 1996 r. o muzeach, Dz.U. $1997 \mathrm{nr} 5$ poz. 24 z późn. zm.).

The Act on Heritage Protection and Maintenance of 23 July 2003, Journal Laws of 2003, No. 162, item 1568, as amended (Ustawa z dnia 23 lipca 2003 r. o ochronie zabytków i opiece nad zabytkami, Dz.U. 2003 nr 162 poz. 1568.).

Timothy, D. \& Boyd S. (2003). Heritage Tourism. Harlow: Pearson Education.

Towse R. (2011), Ekonomia kultury. Kompendium, Warszawa: Narodowe Centrum Kultury.

United Nations World Tourism Organization (UNWTO) (2017) Understanding Tourism: Basic Glossary. Retrieved from http://cf.cdn.unwto.org/sites/all/files/docpdf/glossaryenrev. pdf.

Urbanek, G. (2012). Strategiczne znaczenie marki w działalności organizacji. Marketing instytucji naukowych i badawczych, 1(2), 137-145.

Weisberg, R.W. (2006). Creativity: Understanding Innovation in Problem Solving, Science, Invention and the Arts. Hoboken, New Jersey: John Wiley\&Sons,

Zieliński, M. \& Kubacki, M. (2014). Marka we współczesnej gospodarce. Zeszyty Naukowe Uniwersytetu Szczecińskiego. Finanse, Rynki Finansowe, Ubezpieczenia, 66, 705-719. 